\title{
VIRUS SURVEYS OF LETTUCE CROPS AND MANAGEMENT OF LETTUCE BIG-VEIN DISEASE IN NEW ZEALAND
}

\author{
J.D. FLETCHER ${ }^{1}$, C.M FRANCE ${ }^{2}$ and R.C. BUTLER ${ }^{1}$ \\ ${ }^{1}$ Crop \& Food Research, Private Bag 4704, Christchurch, New Zealand \\ ${ }^{2}$ LeaderBrand Produce, Lytton Rd, Gisborne, New Zealand \\ Corresponding author: fletcherj@crop.cri.nz
}

\begin{abstract}
Virus surveys of lettuce crops over the past three seasons have confirmed that a number of virus diseases can threaten production. Lettuce big-vein disease (LBVD), caused by Mirafiori lettuce big-vein virus (MLBVV) usually in combination with Lettuce big-vein virus (LBVV), was the most widespread virus disease of lettuce over the survey period. Other viruses present include Lettuce necrotic yellows virus (LNYV), Beet western yellows virus (BWYV), Cucumber mosaic virus (CMV) and Lettuce mosaic virus (LMV). The surveys have not detected Tomato spotted wilt virus (TSWV) or Tobacco necrosis virus (TNV). Control of Olpidium brassicae, the fungal vector of LBVD, is an important factor in disease management. This paper outlines survey results and describes experiments using fungicides to control this disease.

Keywords: virus diseases, surveys, lettuce, lettuce big-vein disease, fungicides.
\end{abstract}

\section{INTRODUCTION}

Green salad crops are an important component of fresh vegetable production in New Zealand and outdoor lettuce production forms a major component of this industry. In 2003 growers and processors along with the MAF Sustainable Farming Fund initiated a research project (Walker et al. 2003a,b) to improve integrated pest management (IPM) within the lettuce production industry. This programme focussed on the management of insect pests and diseases of lettuce, including plant viruses.

Virus diseases recorded on outdoor lettuces in New Zealand include: Arabis mosaic virus (ArMV), Beet western yellows virus (BWYV), Cucumber mosaic virus (CMV), Lettuce big-vein virus (LBVV), Lettuce mosaic virus (LMV), Lettuce necrotic yellows virus (LNYV), Tobacco necrosis virus (TNV), Tomato spotted wilt virus (TSWV) and Turnip mosaic virus (TuMV) (Pennycook 1989; Pearson et al. in preparation). Although no virus disease surveys had been published since the 1950s (Fry 1952, 1958; Chamberlain 1954) anecdotal evidence indicated that LBVV and other viruses including LMV, CMV, LNYV, TSWV and BWYV continued to be a problem in field lettuces, whereas TuMV, TNV and ArMV appear to be rarely recorded. With changes in production and the introduction of new insects that may also vector viruses it was important to define the current status of virus diseases in lettuce.

Fry (1958) found that fungicides could reduce the incidence of LBVV by controlling its soil dwelling Chytridiomycete vector Olpidium brassicae. Viruses are transmitted by the motile zoospores of $O$. brassicae as they penetrate the host plant root system. Olpidium brassicae also transmits TNV in lettuce. The use of fungicides had been successfully applied overseas (Walsh 1998) but had not been further explored in New Zealand. Experiments to determine which chemicals might have a potential use to limit LBVV were also initiated as part of this programme. 
The preliminary results of the surveys and chemical control experiments completed in 2002-2003 have been reported (Fletcher et al. 2004). This paper summarises the full set of surveys and chemical control experiments completed as part of the Sustainable Farming Fund project during 2002-2004.

\section{MATERIALS AND METHODS}

Surveys of lettuce crops for viruses recorded in New Zealand, as listed above, were undertaken during 2002-2004 over the spring/summer and autumn/winter periods in cropping areas around Pukekohe, Gisborne, Hastings, Kapiti Coast, Christchurch and Nelson. Primary focus continued in the first two regions where production is greatest. Crops were surveyed along crop rows or in a 'W' pattern and visual estimates of virus incidence recorded. Incidence was estimated particularly from observations of plant stunting and yellowing, leaf mottle/mosaic/necrosis and big-vein symptoms. Individual representative leaf and plant specimens were collected from each crop and bagged for laboratory examination and confirmation of visual diagnoses. Laboratory examination included confirmation of disease symptoms using reliable references (McDougall \& Creek 2003; Davis et al 1997), double antibody sandwich and indirect enzyme-linked immunosorbent assays (ELISA) of each specimen and, where applicable, confirmatory inoculation onto suitable herbaceous indicator hosts (Brunt et al. 1996). Double or triple antibody sandwich ELISA were performed according to the manufacturer's protocols and indirect ELISA was performed according the method of Fletcher (1993). Viruses causing LBVD were initially determined serologically using an antibody to Mirafiore lettuce big-vein virus (MLBVV) (Dr HJ Vetten, Germany), the virus now known to cause the characteristic big-vein disease symptom of LBVD complex (Rogegero et al. 2003). LBVV itself while almost always present in this complex apparently does not cause big-vein symptoms. In the 2004 survey both viruses were further differentiated using an antibody specific to LBVV (Dr RAA Van der Vlugt, The Netherlands).

A field trial was established in November 2003 (late spring) at Makauri, Gisborne, and harvested in late December. The six chemical treatments (Table 1) plus a nil-treatment control were applied to 20-plant plots of cv. Target. Experimental application rates and methods were derived from Walsh (1998) or from similar uses currently recommended in the New Zealand Agrichemical Manual 2002 (Table 1). The trial was established within a commercial field with a history of LBVD. There were five replicates of the seven treatments laid out in a row and column randomised block design. Two further trials were established at the same site using the same design in March 2004 (autumn/ winter) and June 2004 (winter). Transplant cells were drenched in fungicide in the glasshouse the night before planting and soil band application was applied and mixed in after transplanting. Individual plants were assessed at harvest for LBVD symptoms and lettuce heads were weighed.

Mean lettuce head weight (ignoring infection) and yield of healthy lettuces were analysed with analysis of variance. The percentage of infected lettuces per plot were analysed with a binomial generalised linear model (McCullagh \& Nelder 1989), which takes into account the total number of lettuces in each plot. The effect of LBVD on mean weight was examined by including big-vein presence/absence in a mixed model analysis fitted with residual maximum likelihood (REML). This also allowed an examination of whether the effect of big-vein varied between the treatments. Comparisons between treatments were made as part of each analysis, and a level of $\mathrm{P}=0.05$ was used throughout to determine significance. Analyses were carried out with GenStat Release 7.1 (VSN International Hemel Hempsted, UK, 2003).

\section{RESULTS}

LBVD (LBVV \& MLBVV) was the most widespread virus disease of lettuce over the survey periods (Table 2). Prevalence (proportion of infected crops) of LBVD was high (up to $41 \%$ ), as expected under cool winter conditions, but was also high under spring and summer conditions (up to $66 \%$ in some areas, such as Hawke's Bay and Kapiti Coast). 
TABLE 1: Chemical treatments used to control $O$. brassicae.

\begin{tabular}{llccc}
\hline Fungicide & Trade name/active & Application & Rate & Action \\
\hline Carbendazim & Prolific & cell transplant & 20 & systemic \\
& $500 \mathrm{~g} / \mathrm{kg}$ & drench & $\mathrm{g} /$ litre & (acropetally) \\
Propamocarb & Previcur & cell transplant & 1.5 & protectant systemic \\
& $600 \mathrm{~g} /$ litre & drench & $\mathrm{ml} /$ litre & (acropetally) \\
Thiabendazole & Tecto & cell transplant & 10 & systemic \\
& $450 \mathrm{~g} /$ litre & drench & $\mathrm{ml} /$ litre & (acropetally) \\
Fluazinam & Shirlan & soil band & 12 & protectant, some \\
& $500 \mathrm{~g} /$ litre & application & $\mathrm{ml} /$ litre & systemic \\
Flusulfamide & Nebijin & soil band & 3 & spore germination \\
& $50 \mathrm{~g} /$ litre & application & $\mathrm{ml} /$ litre & inhibitor \\
Quintozene & Terrachlor & soil band & 2 & contact fungicide \\
& $750 \mathrm{~g} /$ litre & application & $\mathrm{g} /$ litre & \\
\hline
\end{tabular}

Incidence of LBVD within individual crops followed a similar pattern. In 2004 both viruses comprising the LBVD complex were detected in Pukekohe (32\% prevalence of LBVV and $30 \%$ prevalence of MLBVV) and Hawke's Bay (40\% prevalence of LBVV and $36 \%$ prevalence of MLBVV), but in Gisborne only MLBVV (23\% prevalence) was found. Mixed infections were found in $9 \%$ of Pukekohe crops and $10 \%$ of those in Hawke's Bay.

Other viruses present included LNYV, CMV, BWYV, LMV and occasionally TuMV. These viruses infected up to $58 \%$ of surveyed crops within a region, but incidence within crops was low with only a few scattered plants infected. Often multiple virus infections of individual plants were recorded, for example LMV and LBVD were sometimes found in combination. TSWV, ArMV and TNV were not detected in these surveys.

TABLE 2: Prevalence of lettuce crops affected with viruses ( $\%$ crops within each region) and range of incidence within crops (\% - in parentheses) in four surveys carried out during 2002-2004.

\begin{tabular}{|c|c|c|c|c|c|c|}
\hline & LBVD & LNYV & CMV & BWYV & LMV & TuMV \\
\hline \multicolumn{7}{|c|}{ Spring/summer 2002} \\
\hline Pukekohe & $66(0-2)$ & 0 & 33 & 0 & 11 & 0 \\
\hline Gisborne & $42(10-50)$ & 0 & 14 & 0 & 28 & 0 \\
\hline Christchurch & $10(0-1)$ & 0 & 0 & 10 & 0 & 10 \\
\hline \multicolumn{7}{|l|}{ Winter 2003} \\
\hline Pukekohe & $41(8-50)$ & $58(1-8)$ & 17 & $41(2-20)$ & 0 & 0 \\
\hline Gisborne & $20(1-20)$ & 0 & 0 & 0 & 10 & 0 \\
\hline Christchurch & $20(10-30)$ & 0 & 0 & 0 & 0 & 0 \\
\hline \multicolumn{7}{|c|}{ Spring/summer 2003} \\
\hline Gisborne & $10(0-40)$ & $20(10)$ & 0 & 0 & 20 & 0 \\
\hline Hawke's Bay & $50(5-25)$ & 20 & 0 & 0 & 20 & 0 \\
\hline Kapiti Coast & $66(10-20)$ & 0 & 0 & 0 & 0 & 0 \\
\hline Nelson & $20(1-10)$ & 0 & 0 & 0 & 0 & 0 \\
\hline \multicolumn{7}{|c|}{ Spring/summer 2004} \\
\hline Auckland $^{1}$ & $59(4-25)$ & 0 & 0 & 27 & 0 & 0 \\
\hline Gisborne & $23(1-50)$ & 20 & 8 & 8 & 54 & 0 \\
\hline Hawke's Bay & $60(5-30)$ & 10 & 30 & 0 & 10 & 0 \\
\hline
\end{tabular}

${ }^{1}$ Pukekohe, Bombay and Mangere. 
Results from the first fungicide trial are shown in Table 3. In this spring trial there were no significant differences in mean head weight over all lettuce plants between treatments and the nil treatment. There were no significant differences in the mean yield of healthy plants between any treatment and the nil treatment. The percentage of infected lettuces did not vary significantly between the treatments. However, lettuce plants infected with LBVD (613 g/plant) were significantly lighter than healthy/uninfected lettuces (731 g/plant). This reduction (118 g/plant or $16 \%)$ was similar for all treatments.

TABLE 3: Yield of lettuces (kg/plot) and mean lettuce head weight (g) from different fungicide treatments to control $O$. brassicae in spring/summer (November) 2003.

\begin{tabular}{|c|c|c|c|c|c|c|}
\hline \multirow[b]{2}{*}{ Treatment } & \multirow[b]{2}{*}{$\begin{array}{l}\% \text { lettuces } \\
\text { infected }\end{array}$} & \multirow[b]{2}{*}{$\begin{array}{l}\text { Yield of } \\
\text { healthy } \\
\text { lettuces }\end{array}$} & \multicolumn{4}{|c|}{ Mean lettuce head weight (g) } \\
\hline & & & All plants & $\begin{array}{l}\text { Healthy } \\
\text { plants }\end{array}$ & $\begin{array}{c}\text { Plants with } \\
\text { LBVD }\end{array}$ & $\begin{array}{c}\text { Reduction } \\
\text { (Healthy- } \\
\text { LBVD) }\end{array}$ \\
\hline Control & 26 & 11 & 702 & 730 & 621 & 109 \\
\hline Carbendazim & 24 & 11 & 711 & 734 & 638 & 96 \\
\hline Propamocarb & 21 & 12 & 734 & 764 & 616 & 148 \\
\hline Thiabendazole & 20 & 11 & 683 & 701 & 610 & 92 \\
\hline Fluazinam & 31 & 9 & 633 & 662 & 568 & 94 \\
\hline Flusulfamide & 21 & 12 & 758 & 783 & 660 & 122 \\
\hline Quintozene & 24 & 11 & 704 & 743 & 580 & 163 \\
\hline \multicolumn{2}{|c|}{$\operatorname{LSD}(\mathrm{P}=0.05, \mathrm{df}=24)$} & 1.8 & 75 & & $91^{1}$ & $95^{1}$ \\
\hline
\end{tabular}

${ }^{1}$ Each comparison of two means has a different LSD because the numbers of lettuces vary. This is the mean of all of the LSDs.

In the March 2004 trial (Table 4) fluazinam treatment significantly reduced mean head weight of all plants, which was less than half that found with any of the other treatments including the nil treatment. Propamocarb and thiabendazole treatments significantly increased the mean lettuce weight compared to the nil treatment, but the other fungicide treatments did not differ. There were no significant differences between the weights of LBVD infected and uninfected lettuces. However, the proportion of infected lettuces was noticeably greater for fluazinam and quintozene than for the control; all other treatments had similar infection levels to the control.

TABLE 4: Yield of lettuces (kg/plot) and mean lettuce head weight (g) from different fungicide treatments to control $O$. brassicae in autumn/winter (March) 2004.

\begin{tabular}{|c|c|c|c|c|c|c|}
\hline \multirow[b]{2}{*}{ Treatment } & \multirow[b]{2}{*}{$\begin{array}{c}\% \text { lettuces } \\
\text { infected }\end{array}$} & \multirow[b]{2}{*}{$\begin{array}{l}\text { Yield of } \\
\text { healthy } \\
\text { lettuces }\end{array}$} & \multicolumn{4}{|c|}{ Mean lettuce head weight $(\mathrm{g})$} \\
\hline & & & All plants & $\begin{array}{l}\text { Healthy } \\
\text { plants }\end{array}$ & $\begin{array}{l}\text { Plants } \\
\text { with } \\
\text { LBVD }\end{array}$ & $\begin{array}{l}\text { Reduction } \\
\text { (Healthy- } \\
\text { LBVD) }\end{array}$ \\
\hline Control & 84 & 1.4 & 441 & 419 & 445 & -26 \\
\hline Carbendazim & 83 & 1.4 & 435 & 444 & 433 & 11 \\
\hline Propamocarb & 85 & 1.4 & 499 & 472 & 503 & -31 \\
\hline Thiabendazole & 92 & 0.7 & 510 & 501 & 512 & -10 \\
\hline Fluazinam & 99 & 0.1 & 192 & 317 & 190 & 126 \\
\hline Flusulfamide & 89 & 1.1 & 468 & 478 & 466 & 12 \\
\hline Quintozene & 99 & 0.1 & 444 & 294 & 446 & -152 \\
\hline \multicolumn{2}{|c|}{$\operatorname{LSD}(\mathrm{P}=0.05, \mathrm{df}=18)$} & 1.4 & 56 & $116^{1}$ & & $146^{1}$ \\
\hline
\end{tabular}

${ }^{1}$ Each comparison of two means has a different LSD because the numbers of lettuces vary. This is the mean of all of the LSDs. 
There were no healthy plants in the June 2004 trial with $100 \%$ infection recorded in all plots so healthy/LBVD yield comparisons could not be made (Table 5). Overall, mean head weight for fluazinam was significantly $(\mathrm{P}<0.05)$ lower than for any other treatment. Mean head weight for quintozene was significantly lower than for the nil treatment, flusulfamide, propamocarb and thiabendazole.

TABLE 5: Mean lettuce head weight (g/plant) from different fungicide treatments to control $O$. brassicae in winter (June) 2004. There was $100 \%$ LBVD infection in all plots.

\begin{tabular}{lcc}
\hline Treatment & $\begin{array}{c}\text { Mean lettuce head } \\
\text { weight }(\mathrm{g})\end{array}$ & $\begin{array}{c}\text { Difference from Control } \\
(\mathrm{g})\end{array}$ \\
\hline Control & 494 & 0 \\
Carbendazim & 456 & -38 \\
Propamocarb & 504 & 10 \\
Thiabendazole & 520 & 25 \\
Fluazinam & 138 & -357 \\
Flusulfamide & 499 & 4 \\
Quintozene & 413 & -81 \\
LSD $(\mathrm{P}=0.05, \mathrm{df}=24)$ & 67 &
\end{tabular}

\section{DISCUSSION}

These surveys have shown that LBVD, caused by a complex of the two viruses MLBVV and LBVV, is widespread in field grown lettuces. Discussions with growers indicate that they don't appear to be very concerned at the losses they are having from LBVD, rather they are resigned to LBVD damage. Other viruses such as LNYV, CMV, LMV, TuMV and BWYV occur, often as mixed infections, but don't cause significant crop losses. TSWV, ArMV and TNV were not detected in any of the surveys.

It is of interest that the thrips-vectored virus TSWV was not detected, particularly with an increasing incidence of Western flower thrips (Frankliniella occidentalis) in field crops such as lettuce around Pukekohe (G.P. Walker \& P.J. Workman, pers. comm.). It is probable that reservoirs of virus infection in nearby weeds are not yet infected with TSWV because few host crops have been grown in the district in recent years. There is no clear reason why this virus was not present in lettuce in regions where TSWV is known to be present, such as Hawke's Bay and Gisborne, where the virus has been found in nearby pepper and tomato crops and weeds (Fletcher 2001; J.D. Fletcher, unpubl. data).

Walsh (1998) found carbendazem gave good control of $O$. brassicae and LBVD symptoms, thiabendazole gave some control but was phytotoxic and fluazinam showed promise in pot trials. The present study found that chemical treatments used to control $O$. brassicae over warm spring/summer conditions have a marginal effect, probably because fungal activity and virus tranmission is at its lowest. However, even under mild weather conditions significant yield losses $(16 \%)$ were found to occur in LBVD infected lettuces.

Chemical treatment for control $O$. brassicae over winter/spring using selected fungicides can increase yield of lettuce plants. Carbendazem, propamocarb and thiabendazole maintained or increased lettuce yield. Chemicals such as fluazinam and quintozene were phytotoxic, but further work on application might improve their efficacy.

\section{ACKNOWLEDGEMENTS}

We acknowledge the financial and in-kind of support of the MAF Sustainable Farming Fund, the NZ Vegetable \& Potato Growers' Federation, and lettuce growers and processors. 


\section{REFERENCES}

Brunt AA, Crabtree K, Dallwitz MJ, Gibb AJ, Watson L 1996. Viruses of plants. Descriptions and lists from the VIDE database. CAB International, Wallingford, UK. $1484 \mathrm{p}$

Chamberlain EE 1954. Plant virus diseases in New Zealand. DSIR Bulletin no 158.

Davis RM, Subbarao KV, Raid RN, Kurtz EA 1997. Compendium of lettuce diseases. APS Press, Minnesota.

Fletcher JD 1993. Surveys of virus disease in pea, lentil, dwarf and broad bean in South Island, New Zealand. New Zealand Journal of Crop \& Horticultural Science 20: 319-37.

Fletcher JD 2001. New plant disease records in New Zealand: further hosts of alfalfa mosaic virus, cucumber mosaic virus, potato virus $\mathrm{Y}$, soybean dwarf virus and tomato spotted wilt virus. New Zealand Journal of Crop \& Horticultural Science 29: 213-217.

Fletcher JD, France C, Butler R 2004. Control and management of lettuce big-vein disease. New Zealand Plant Protection 57: 344.

Fry PR 1952. Lettuce mosaic. New Zealand Journal of Science and Technology A 33(5): 52-63.

Fry PR 1958. The relationship of Olpidium brassicae (Wor.) to the big-vein disease of lettuce. New Zealand Journal of Agricultural Research 1: 303-304.

McCullagh P, Nelder JA 1989. Generalised linear models. Chapman \& Hall, London. $511 \mathrm{p}$.

McDougall S, Creek A 2003. Pests, beneficials, diseases and disorders in lettuce: field identification guide. NSW Agriculture.

New Zealand Agrichemical Manual 2002. D Walton ed. Wham Media, Wellington.

Pennycook SR 1989. Plant diseases recorded in New Zealand. Vol 3, Part V: Viral plant diseases recorded in New Zealand. Plant Diseases Division, DSIR, Auckland. 87-179.

Rogero P, Lot H, Souche S, Lenzi R, Milne R 2003. Occurrence of Mirafiori lettuce virus and Lettuce big-vein virus in relation to development of big-vein symptoms in lettuce crops. European Journal of Plant Pathology 109: 261-267.

Walker GP, Workman PJ, Stufkens MAW, Wright PJ, Fletcher JD, Quereshi MS, Davis SI 2003a. Integrated pest management (IPM) for outdoor lettuce. New Zealand Plant Protection 56: 269.

Walker G, Workman P, Stufkens M, Wright P, Fletcher J, Quereshi S, MacDonald F 2003b. IPM for outdoor lettuce. Grower Dec: 21-24.

Walsh JA 1998. Chemical control of fungal vectors of plant viruses. In: Hadaidi A, Kheterpal RK, Koganezawa H ed. Plant virus disease control. APS, St Paul, Minnesota. Pp. 196-207. 